sales; but the total cost of the Society's activities continues to rise and gives cause for considerable anxiety.

Five science meetings were held in London during 1954, including the summer meeting on July 7,9 and 12, which was held in the Royal Institution in connexion with the General Assembly of the International Union of Pure and Applied Physies. Meotings outside London were held in University College, Dublin, during March 30-April 1, and in the University of Birmingham during December 13-14. In addition, a conference on the physics of the ionosphere was held in the Cavendish Laboratory, Cambridge, during September 6-9. The thirty* eighth Guthrie Lecture ${ }^{1}$ was delivered by Sir Geoffrey Taylor, who spoke on diffusion and mass transport in tubes, and the seventh Rutherford Lecture by Prof. P. M. S. Blackett. Prof. A. Kastler, of the University of Paris, was the recipient of the ninth Holweck Medal of the Société Française de Physique and the Holweck Prize of the Physical Society; the presentation took place at the Royal Astronomical Society, Burlington House, on May 13, 1954, when Prof. Kastler delivered the Holweck discourse ${ }^{2}$ entitled "Les méthodes optiques d'orientation atomique et leurs applications". The thirty-first Duddell Medal was presented to Prof. A. C. B. Lovell, who gave an address on the development and use of large radio telescopes, and the tenth Charles Vemon Boys Prize to Dr. J. S. Courtner-Pratt, who spoke on some new methods of fast photography.

At the request of a number of members, the Society reprinted the first five Rutherford Memorial Lectures; and the pamphlet, entitled "Rutherford, by Those who Knew Him", has been well received. Two special reports, "Defects in Crystalline Solids", representing the proceedings of a conference on this subject held in the University of Bristol during the meeting of the International Union of Pure and Applied Physics, and "The Physics of the Ionosphere", the proceedings of the Cambridge conference on this subject, have recently been issued. Vol. 17 of "Reports on Progress in Physics", containing eight reports, was published during 1954. A new departure was the issue, in addition to the bound volume, of each report as a separate booklet, with paper covers, to be purchased in any required quantity.

'The thirty-eighth annual exhibition of scientific instruments and apparatus held at the Imperial College of Science and Technology, London, during April 8-13, 1954, had an attendance of approximately eighteen thousand and was again a great success. The four subject-groups of the Society-the Colour, Optical, Low Temperature, and Acoustics Groupswere all active during the year, and brief details of their membership and meetings are listed in the annual report. The summer meeting of the Low Temperature Group consisted of a visit, led by Dr. K. Mendelssohn and Dr. F. Din, to West Germany; on May 7 the party inspectod the oxygen plant of tho Mosser Company at Hagen-Haspe, and during May 8-9, at Göttingen, a joint session was held with members of the German Physical Society at which scientific papers were read. A list of the numerous bodies and conomittees on which the Society is represented is also included in the report.

At the annual general meeting the officers and council of the Society for 1955-56 were elected as follows : President, Prof. H. S. W. Massey; VicePresidents, Dr. R. C. Evans, Dr. A. B. Wood, Prof.
S. Devons and Prof. F. Llewellyn Jones; Honorary Secretaries, Dr. C. G. Wynne and Dr. H. H. Hopkins ; Honorary Foreign Secretary, Prof. E. N. da C. Andrade; Honorary Treasurer, Mr. A. J. Philpot; Honorary Librarian, Dr. R. W. B. Pearse; New Ordinary Members of Council, Prof. W. E. Burcham, Prof. H. Jones and Mr. D. A. Wright.

1 Proc. Phys. Soc., B, 67, 857 (1954).

2 Proc. Phys. Soc., A, 67, 853 (1954).

\section{NITROGEN NUTRITION, RESPIRATION AND AGEING IN LEMNA FRONDS}

TN a constant and favourable environment, each frond of Lemna minor has a finite length of life and a rate of ageing characteristic of the clone in its particular environment. Ageing, and the progressive diminution in frond-size which accompanies it, are not attributable to the production of daughter fronds, nor to a lack of auxin or adenine. Further, it has been found in surgical experiments that daughter frond area is determined by some substance in the mother frond (not auxin or adenine) which diminishes or is inactivated as the mother frond ages. E. Wangermann and H. J. Lacey (New Phytol., 54, 2, 182 ; 1955), in further investigations, have examined the relationship between nitrate nutrition, rate of respiration, and rate of ageing in Lemna with the following results.

Maximum length of life and minimum rate of ageing occurred at the lowest nitrogen-levels (less than $0.1 \mathrm{mgm} . / 1$.) ; minimum lengih of life and maximum rate of ageing occurred at intermediate nitrogen levels (about $0.25 \mathrm{mgm} . / 1$.). When rates of respiration of fronds at high and low nitrogen-levels were measured by the Warburg manometric technique, it was found that the rate of respiration of the lownitrogen fronds (on an area or dry-weight basis) was below that of the high-nitrogen fronds throughout the whole of their life. There was no trend towards reduction in rate of respiration between maturity and death. The length of life was recorded of fronds the respiration of which was periodically inhibited by keeping them in an atmosphere of nitrogen during the dark period. Fronds thus treated lived considerably longer than those the respiration of which was not interfered with. From these results and those of previous experiments, it is tentatively suggested that a causal relationship may exist between rate of respiration and rate of agoing, slow respiration resulting in long life and vice versa.

\section{A NEW FAMILY OF EARLY PRIMATES}

$T$ HE known primates and primate-like animals from the Palæocene and Eocene of North America and Europe are extraordinarily diverse. All are distinctly pre-anthropoid in structural grade and are considered in a general sense to be Prosimii or, in some cases, primate-like Insectivora. There has been a tendency to compare them either with the tarsiers or lemurs and to place them in the categories Tarsiiformes and Lemuriformes. Most of the supposed early Tarsiiformes have been classified 